\author{
Верелейчик C.B., \\ здобувач кафедри фбілософбї \\ Національного університету водного господарства та природокористування
}

\title{
ДУША У ФІЛОСОФСЬКОМУ ДИСКУРСІ НІМЕЦЬКОЇ КЛАСИЧНОЇ ФІЛОСОФІЇ
}

Анотація. У статті проводиться аналіз філософських концепцій Г. Гегеля й І. Канта в напрямі формування підходів до розуміння феномену людської душі. Водночас висвітлено становлення передумов, що дали поштовх у своєрідному еволюційному кроці в питаннях душевної природи та переосмислення метафізичного напряму у філософії початку XIX століття. У процесі дослідження висвітлено передумови виникнення світоглядної парадигми німецької школи класичної філософії та розкрито сутність співвідношення у трансцендентальній сфері взаємодії душі із середовищем «чистого розуму» та внутрішнім принципом моральної свободи, що бере свій початок із стихії природного духу. У дослідженні розкрито феномен душі в контексті гносеології трансцендентального через аналіз душевно-тілесної взаємодії. У результаті аналізу такого явища, як «душа», у контексті антропологічних пошуків Г. Гегеля й І. Канта встановлено, що існування морально-етичних законів, обгрунтування яких полягає у визнанні права на буття надприродної сутності, фактично є єдиним зумовленим аргументом в онтологічній обгрунтованості вищої істоти. У статті визначено, що, згідно з ученням I. Канта, усе, що не $\epsilon$ цариною «чистого розуму», у трактуванні душевних проявів повинно відігравати другорядну роль. Установлено, що гегелівська експлікація душі в полі «усезагального» представляє іiї духовним джерелом у стані матеріалістичної природи. Розкрито етапи розвитку духу на основі самоочищення душі від тілесності. Здійснено порівняльний аналіз таких понять, як «феноменальна інтенсивність» та «інтенсивність духу» у філософуванні I. Канта та Г. Гегеля. Встановлено, що в Г. Гегеля, на противагу I. Канту, вкоріненість душевної інтенсивності є не трансцендентальною, а антропологічною. У результаті дослідження з'ясовано, що сутність розуміння такого явища, як душа, є своєрідним втіленням парадоксального поєднання апогею й одночасно вгасання епохи раціональності. Символізм такого синтезу пояснюється в дослідженні тим, що І. Кант у процесі подолання метафізичної спадщини так і не спромігся переступити через догматичну секуляризованість західної церкви. Встановлено, згідно із вченням Г. Гегеля, що необхідно підпорядкувати свою душу, iї інтенсивність вищому в собі, тобто духові.

Ключові слова: Гегель, Кант, душа, дух, розум, трансцендентність, філософська антропологія.

Постановка проблеми. Душа - один із найважливіших феноменів онтологічної дійсності особистості, який супроводжує людину весь період іiі життя, а також впливає як опосередковано, так і безпосередньо на рівень причетності саме до осмисленого буття. Саме тому проблематика душі є актуальною та невичерпною, оскільки пов'язана 3 такими поняттями, як «свідомість», «дух», «мислення», «пізнання», центральне місце в дослідженні яких відводиться саме у період німецької класичної філософії. Цей період у філософії став своєрідним підсумком розвитку всієї попередньої європейської філософії та джерелом подальшого розвитку філософської думки.

Хоча німецька класична філософія не мала порівняно цілісного напряму, проте їй властива певна тематична єдність досліджень, зокрема і духовного світу людини. Якщо у філософіï середніх віків душа розглядалася як безтілесна, то в період Нового часу посилюється позиція противників даного підходу, що і змінило спосіб критики метафізичного розуміння душі.

Аналіз останніх досліджень і публлікацій. Хоча на даний момент існує досить багато досліджень в області філософської спадщини Г. Гегеля й І. Канта, проте доречно було б виділити, у контексті вивчення проблематики душі, таких науковців: К. Чепуріна, Т. Базулєва, А. Положенцева, Л. Криштопа, О. Баніже, А. Вавілова, М. Зуй, І. Протопопова, Н. Рум'янцева, О. Марєєва, В. Півоєва.

Мета статті - висвітлення феномену душі в контексті аналізу душевно-тілесної взаємодії у філософії Г. Гегеля й І. Канта. Вищевказана ціль досягається шляхом розкриття сутності людської душі через трансцендентальний підхід І. Канта на основі співвідношення «чистого розуму» i внутрішньої моральної свободи та висвітлення гегелівської антропологічної позиції в поясненні інтенсивного характеру душевної індивідуальності. Водночас наводяться передумови, що дали поштовх у своєрідному еволюційному кроці в питаннях душевної природи та переосмислення метафізичного напряму у філософії початку XIX ст.

Виклад основного матеріалу дослідження. Перед тим як розглянути проблематику душі в контексті німецької класичної філософії, варто зазначити, що з початком Новітнього часу в суспільстві поступово посилюється явище секуляризації. I душа як інтелігібельна сутність у світогляді «нової» людини починає висвітлюватися з позиції науки. У розрізі даного етапу формування філософської думки варто звернути увагу на позицію Джона Локка, який у потоці панівної емпірії намагався поєднати практичний досвід із розумінням душевної ідеальності. Де-факто філософ дотримується у своїх поглядах дуалізму в підході до процесу дослідження душевної природи людини. Тому водночас із сумнівами щодо душі як нематеріальної сутності він стверджує ідею безтілесності людського духа, обгрунтовуючи це через здатність думки до трансформації фізики людського буття.

Своєрідність такого підходу Дж. Локка до природи душі полягає в тому, що в полі проблематики питання свого походження вона є гармонічно вбудованою в ідею ідеального Абсолюту. Проте в дискурсі філософської парадигми Девіда Юма, на відміну від Дж. Локка, теоретичні настанови есенціалізма 
цілком відкидаються філософом, фактично в його роботах простежується чітка лінія скептицизму як щодо матеріалізму, так і стосовно ідеалізму.

Зауважимо, що саме скептицизм Д. Юма надав поштовх до звільнення I. Канта від догматичних кайданів метафізики. На думку філософа, основа раціональної психології полягає саме в онтологічному стані буттєвості логічної функціональності індивідуального мислення. Але оскільки в контексті розуміння логічного судження підсумок дискурсивного міркування прирівнюється до «метафізичного визначення об'єкта» [1, с. 375], у процесі якого між аналітичним і синтетичним ставиться знак рівності, то відповідно обгрунтування сутності душі буквально береться $з$ повітря.

Саме тому у філософії І. Канта зміст рефлексивного передусім відображає монолітність досвідного сприйняття, тобто трансцендентальна єдність апперцепції в розумінні філософа постає у вигляді апріорної цілісності самосвідомості, тобто виявляється саме тим, що в метафізиці іменується душею [1, с. 196]. Отже, розглядаючи образ душі, I. Кант у рамках своєї трансцендентальної критики трактує іiі як регулятивну ідею розуму, яка є важливим елементом у процесі пізнання: «Розум ніколи прямо не стосується предмета, а стосується тільки розуму, і за допомогою нього - свого власного емпіричного застосування; він не створює жодних понять (про об'єкти), а тільки впорядковує їх і дає їм ту єдність, яку вони можуть мати за максимального свого розширення, тобто у ставленні до сукупної цілісності рядів» [1, с. 552]. Отже, завдання розуму, у контексті кантіанства, полягає саме в інкапсуляції систематичності у процес пізнання, де однією з функцій такої реалізації, на думку філософа, виступає психологічна ідея.

Даючи оцінку вищезазначеному явищу, I. Кант звертає увагу на те, що саме психологічна ідея, яка буквально є усвідомленням інтелекту сутності простої субстанції і лежить в основі тотожності особистості, виступає певним принципом у спробі роз'яснення сутності душі. «Така психологічна ідея, - стверджує філософ, - може бути цілком корисною, якщо тільки ми будемо остерігатися приймати іiі за щось більше, ніж тільки за ідею, тобто якщо вважатимемо їі придатною тільки для систематичного застосування розуму до явищ нашої душі» [1, с. 579]. Душа як елемент, що вносить упорядкованість в акт пізнання, використовується I. Кантом за деякий трансцендентальний зразок, проте без перенесення внутрішнього світу людини на поле фізичної реальності, як це робила раціональна психологія. Зауважимо, що у процесі об'єктивації етичного моральна ідея як втілення об'єктивної реальності впливає на емпірично осяжний світ із метою узгодження його 3 «моральним законом» [1, с. 663].

Для самітника з Кенігсберга існування трансцендентального Абсолюту насамперед було зумовлено не так раціональною необхідністю, як постулатами моральності. Також за визнання буття Бога логічним $є$ припущення філософа про існування безсмертної душі. Оскільки питання божественної природи для І. Канта лежить в полі етичного, то душа 3 позицій теоретичного розуму являє собою апріорну єдність самосвідомості, а не мислячу субстанцію. Тому вирішення питання безсмертності душі філософ пропонує прийняти у вигляді постулату практичного розуму. Даючи оцінку даній концепції через розуміння святості як втілення синергії вольової та моральної компонент, І. Кант зауважує, що в чуттєвому світі таке поєд- нання неможливе, тому що останнє передбачає безмежний розвиток. Із чого випливає, що довершеність моральної чистоти детермінує онтологічну безкінечність безкрайньої особистості, що рівносильно розумінню поняття безсмертної душі. «Отже, вище благо практично можливо, - пише I. Кант, - тільки за допущення безсмертя душі, відповідно це безсмертя, яке нерозривно пов'язане з моральним законом, є постулат чистого практичного розуму < ..>> [2, с. 375]. Такий постулат, на думку філософа, буквально визначає непогрішимість морального закону, адже його відсутність дає можливість для егоїстичного маніпулювання в середовищі етичних норм [2, с. 376].

Нагадаємо, що раціональна психологія у процесі творіння людської душі в полі просторово-часової безкінечності не виходить за межі своєї метафізичної реальності, тим самим визначає душу як розуміння найпростішого, єдиного та незмінного. Прикладом такої субстанціалізації душі є вчення Декарта, у руслі якого йдеться про кооперацію душевної та тілесної субстанцій у точці взаємодії, що є основою душі. Проте, на думку Г. Гегеля, антиподом в даному питані виступає спекулятивна логіка, яка в особі I. Канта зробила якісний перехід від структурованого дослідження психічного до рефлекторної свідомості, тим самим надавши поштовх у міркуваннях Й. Фіхте до діалектики «Я» та «не Я». Аналогічно у філософії духа Г. Гегеля перехід від душі до самосвідомості відбувається спекулятивним чином. Отже, можна стверджувати, що свідомість у потоці філософування німця уподібнюється "deusex machina". Так, для філософа справжньою ціллю самопізнання передусім є не індивідуальність «вигинів людського серця», а всезагальне. Тобто для Г. Гегеля неповторність людської особистості становить інтерес лише за ототожнення іiі з поняттям універсального [3, с. 7]. Цікавим моментом у гносеологічному дискурсі рефлексії ідеально-безтілесного є візуалізація філософом процесу самопізнання Абсолютного духу через геометрію топології кола, де душа в потоці циклічної динаміки виступає всього лише моментом саморуху всезагального в рефлексивній дії над досконалою ідеєю.

У подальшому Г. Гегель піддає дух посиленому форсуванню 3 метою його пробудження у предметній дійсності. У вченнях філософа природна душа після такої духовної метаморфози намагається звільнитися від матеріальної оформленості. «Дух є екзистуюча істина матерії, - пише щодо цього Г. Гегель, - істина, яка полягає в тому, що сама матерія не має своєї істини» [3, с. 44]. У такому разі для Г. Гегеля є справедлива концепція світової душі як втілення центральної сутності космосу. І хоча в цій позиції все ще спостерігається «сон духу», проте саме в елементарних проявах фауни та неживого світу природи відбувається духовна персоніфікація матерії. «Душа є щось всеохоплююче, - уточнює філософ, - а не щось існуюче тільки в окремому індивідуумі» [3, с. 155]. Тому, на думку філософа, саме пантеїзм і $є$ відображенням початкового етапу гілозоїзації матерії.

Проте саме у філософській доктрині Б. Спінози Г. Гегель вбачає суттєвий недолік, зміст якого полягає в тому, що «субстанція не досягає в ній свого іманентного розвитку - різноманіття тільки зовнішнім чином приєднується до субстанції» [3, с. 46]. Варто уточнити, що така світоглядна парадигма, на думку філософа, втілюється в життя у формі позитивного та чуттєвого сприйняття світобудови і $€$ вихідним пунктом для кожного індивіда в період його квітучої юності, оскільки «так знаходимо ми 
відчуття світової душі, єдності духу із природою, імматеріальності самої природи» [3, с. 46]. Отже, душа у вченні Г. Гегеля знаходиться посередині між природою та світом моральної свободи, що походить із природного духу [3, с. 53].

Однак, на думку філософа, у контексті власного еволюційного розвитку психея не повинна зупинятися у своєму прогресі на тлі зовнішньої конфронтації з тілом. Подолати вищезазначений дуалізм Г. Гегель намагається, з одного боку, звертаючись до досвіду Р. Декарта, Н. Мальбранша та Б. Спінози, у філософському дискурсі яких душевно-тілесна відмінність нівелюється в Абсолюті, шляхом їх тотожності. А з іншого боку, через трактування душі як внутрішнього принципу людського тіла: «У своїй тілесності, перетвореною душею і нею освоєною, пише Г. Гегель, - душа виступає як одиничний суб'єкт для себе, а тілесність $€$, таким чином, зовнішністю як предикат, у якому суб'єкт відноситься тільки до самого себе. Ця зовнішність представляє не себе, але душу, і $€$ iї знаком» [3, с. 53]. Тут під зовнішністю філософ має на увазі саме обличчя людини, вкладає в нього зміст «дзеркала душі».

Крім того, до найбільш характерних критеріїв, що відображають духовну сутність особистості, Г. Гегель також відносить і тілесну конституцію. Зауважимо, що тіло розглядається філософом тільки у співвідношенні з душею. Варто зазначити, що таку тотожність Г. Гегель в основному позв'язує із тваринним буттям, тоді як мислення та самосвідомість розглядаються ним лише у взаємозв'язку з навколишнім світом. За такого напряму вектора, у бік усезагального в руслі філософської антропології, Г. Гегель пропонує розглянути дух у категорії інобуття, де прикладом такого природного стану якраз і $є$ душа. Тому де-факто можна сказати, що душа у вченні Г. Гегеля являє собою духовне джерело в середовищі матеріалістичної природи [4, с. 265].

У даному напрямі особливим об'єктом дослідження для Г. Гегеля є процес звільнення духа від його тілесності. Філософ зазначає нерозривність духовного та тілесного життя. Важливо зауважити, що на першій стадії свого розвитку дух ще не повною мірою є своєю сутністю, а є безпосереднім «природним духом», або душею. Це дух, тісно пов'язаний із тілесністю, він «полонений природою», представляється як «сон духу»пасивний дух Аристотеля. Тобто на даному етапі людська душа $€$ духом, який поки що є пасивним. Однак це $є$ першим ступенем піднесення духу до духу. Отже, людська душа, хоч і занурена ще у природу, але вже визначається як безпосередній дух. Ії сутність визначає не природа, а дух.

Зважаючи на вищенаведене, варто зазначити, що Г. Гегель розглядає душу на межі між біологією як заключною частиною «Філософії природи» та «Філософією духу». Вище душі перебуває все, що становить предмет феноменології духу, а ще вище - предмет психології, де дух звільняється від безпосереднього зв'язку з тілом. Фактично весь розвиток духу являє собою боротьбу з тілесністю, щоб ії зменшити та побороти [5].

Згідно з ученням Г. Гегеля, на шляху самоочищення душі від тілесності дух проходить три основні етапи:

1. Пасивної єдності душі та природи (тут філософ аналізує кліматичні впливи на психіку, расові відмінності, особливості національних характерів, темпераментів та ін.).

2. Боротьби душі проти їі єдності з тілом.

3. Перемоги душі над тілом, коли вона «відкидає від себе тілесність як щось їй чуже» [3, с. 217].
Отже, людська душа, за Г. Гегелем, є безпосередньо духовною сутністю, яка визначена і наповнена духом, а також є онтологічно іншою, ніж душа тварини. Унаслідок цього філософ наділяє душу людини двома основними антропологічними критеріями: «інтенсивністю» та «долею». Саме ці критерії свідчать про іiї призначення. Душа людини характеризується особливим проявом індивідуальності - «інтенсивною формою», яка, згідно із вченням філософа, включає в себе антропологічну «долю» індивіда, що задає напрям усього його життя, чого немає у тварини. Доля індивіда за своїм призначенням служить духу, тому людська воля теж повинна виконувати цю функцію. I саме можливість направити свою долю згідно із цілями духу, а не «руйнувати цілі долі», що, на думку філософа, часто буває властиво «сучасній людині», закладена в душі людини.

Поняття «інтенсивність душі» Г. Гегель запозичує з філософії І. Канта, але видозмінює його суть [6]. У своїй праці «Наука логіки» зазначає, що саме I. Кант першим порушив тему душевної інтенсивності, застосувавши визначення інтенсивної величини («інтенсивної кількості») саме до «метафізичного визначення душі» [7]. Однак на основі духовного визначення людської душі Г. Гегель критикує кантівське розуміння душевної інтенсивності як кількості. Варто зазначити, що Г. Гегель цілком не відмовляється від концепції душевної інтенсивності, а розрізняє два іiї типи: речову (феноменальну інтенсивність) і духовну (інтенсивність духу). Душа, згідно із вченням Г. Гегеля, є не річчю, а формою духу. Дух же володіє «цілком іншою інтенсивністю», ніж феноменальна інтенсивність, яка підпадає під категорію «кількості». Тобто в суперечці з І. Кантом Г. Гегель зводить інтенсивність душі до інтенсивності духу, а не до «речі». Інтенсивний характер душевної індивідуальності («інтенсивна форма індивідуальності», інтенсивне «ядро» індивідуальної людської душі) виступає в Г. Гегеля як важливий наслідок духовної визначеності душі людини.

Однак варто зазначити, що Г. Гегель цілком не відкидає вчення I. Канта, зберігаючи лише духовний різновид інтенсивності. Філософ звертається також до кантівської феноменальної інтенсивності, але лише як до частини своєї феноменології. Однак Г. Гегель кардинально змінює підхід до даного поняття, надаючи йому антропологічної основи, а не трансцендентальної, вкорінюючи цю категорію в людській душі як форми духу, а не в активності пізнавального суб'єкта. Тобто в І. Канта всяка феноменальна активність душі (наприклад, свідомість) укорінена у трансцендентальній формі інтенсивності, в інтенсивності як апріорній формі [8].

У Г. Гегеля ж укоріненість душевної інтенсивності $€$ не трансцендентальною, а антропологічною. Тобто саме феноменологічна («феноменальна») інтенсивність свідомості заснована на антропологічній інтенсивності душевного «ядра», яка і надає свідомості інтенсивності. Як зазначалося вище, лише феноменологічна інтенсивність підпадає під визначення кількості. Інакше кажучи, за Г. Гегелем, не може бути кількісної (феноменологічної) інтенсивності душевних сил без початкової (антропологічної) інтенсивності душевного «ядра», яка і наділяє інтенсивністю будь-яку активність душі, зокрема іiі «свідому» активність.

Саме тому, згідно із вченням Г. Гегеля, зовнішній світ і відповідає співмірності душі, адже він визначається інтенсивністю iii «ядра», з якого цей світ і проводиться, виноситься назовні. Тим самим, з огляду на загальну логіку руху суб'єктивного духу, 
стає зрозумілим, звідки тут береться «співмірність», інакше кажучи, відповідність «масштабу» зовнішнього світу «масштабу» його душі, тобто «інтенсивної форми індивідуальності».

Згідно з «феноменологією духу», самосвідомість підлаштовує, тобто робить сумірною, відповідно до своєї величини, ту дійсність, горизонт якої заданий початковим «перетворенням у дійсність» його душі. I «міць індивіда полягає в тому, що він робить себе сумірним цій субстанції», тобто в досягненні всієї потенційно доступної даному індивіду повноти, закладеної в його «енергії характеру і таланту» [9, с. 252].

Отже, згідно з філософією Г. Гегеля, необхідно підпорядкувати свою душу, іiі інтенсивність вищому в собі, тобто духові. Отже, духовний смисл надається самій антропології. Інтенсивність душі дарована людині духом, відповідно саме до духу вона і повинна повернутися. Тільки тоді абсолютний дух зможе прийти до самого себе. Отже, із вчення Г. Гегеля стає зрозумілим, що людина не тільки здатна до праці над собою, до перетворення себе, але в їі душі вже закладена можливість того, що ця праця принесе плоди.

Висновки. У філософському дискурсі представників німецької школи філософії Г. Гегеля й І. Канта сутність розуміння такого явища, як душа, є своєрідним втіленням парадоксального поєднання апогею й одночасно вгасання епохи раціональності. Символізм такого синтезу полягає в тому, що I. Кант у процесі подолання метафізичної спадщини так і не спромігся переступити через догматичну секуляризованість західної церкви. Усвідомлення душі як субстанції філософ впевнено розвінчує. Проте саме чинник морального Абсолюту виявляється перепоною, що зумовлює право на існування душі у філософській доктрині І. Канта. Проводячи зріз концепції філософа, варто зауважити, що всяка феноменальна активність душі (наприклад, свідомість) укорінена у трансцендентальній формі інтенсивності, в інтенсивності як апріорній формі.

Г. Гегель кардинально змінюе підхід до дослідження душі, надаючи їй антропологічної основи, а не трансцендентальної. Філософ, вкорінюючи цю категорію в людській душі (як форми духу), а не в активності пізнавального суб'єкта, не лише не скористався можливістю розширити методологію трансценденталізму, а, навпаки, поглибив їі обмеженість. На основі вищенаведеного духовний смисл надається самій антропології, відповідно й індивідуальній людській душі. На основі вчення Г. Гегеля стає зрозумілим, що людина здатна до праці над собою та змін, до перетворення себе.

\section{Jimepamypa:}

1. Кант И. Сочинения : в 6-ти т. / под общ. ред. В. Асмуса и др. Москва : Мысль. Т. 6. 1966.743 с.

2. Кант И. Лекции по этике. Москва : Наука, 2000. 431 с.

3. Гегель Г.В.Ф. Энциклопедия философских наук. Т. 3 : Философия духа. Москва : Мысль, 1977. 471с.

4. Мареева Е. Проблема души в классической и неклассической философии. Москва : Академический проект, 2017. 454 с.

5. Румянцева Т. Немецкий идеализм: от Канта до Гегеля : учебное пособие. Минск, 2015. 271 с.
6. Chepurin K. Kant on the Soul's Intensity. Kant Yearbook № 2 : Metaphysics / Ed. Dietmar H. Heidemann. Berlin ; New York, 2010. 29 p.

7. Гегель Г.В.Ф. Наука логики. Санкт-Петербург : Наука, 2002. 201 c. C. 30.

8. Чепурин К. Человеческая душа, её интенсивность и судьба : введение в антропологию Гегеля. История философии. 2012. № 17. C. 141-159.

9. Гегель Г.В.Ф. Феноменология духа. Москва, 2000. С. 252.

Veremeychik S. The soul in the philosophical discourse of German classical philosophy

Summary. The article is devoted to the philosophical concepts of Hegel and Kant in the direction of forming approaches to understanding the phenomenon of the human soul. The formation of the preconditions that gave impetus to a peculiar evolutionary step in the questions of the spiritual nature and a rethinking of the metaphysical direction in the philosophy of the beginning of the XIX century are determined in this article. In the course of the research, the background of the worldview paradigm of the German School of Classical Philosophy is revealed and the essence of the relation in the transcendental sphere of interaction of the soul with the environment of "pure mind" and the internal principle of moral freedom, which originates from the element of the natural spirit, is revealed. The study reveals the phenomenon of the soul in the context of transcendental epistemology through the analysis of the bodily-bodily interaction. As a result of the analysis of such a phenomenon as «soul» in the context of the anthropological searches of Hegel and Kant it is established that the existence of moral and ethical laws, the justification of which is to recognize the right to be a supernatural entity, is in fact the only conditioned argument in the ontological substantiation of a higher being. It is established that the Hegelian explication of the soul in the field of the "universal" represents its spiritual source in the state of materialistic nature. The stages of the development of the spirit based on the self-purification of the soul from physicality are revealed. Comparative analysis of such concepts as phenomenal intensity and intensity of spirit in Kant and Hegel's philosophizing has been carried out. It is established that Hegel, contrary to Kant's view, is rooted in anthropological, not transcendental, mental intensity. The study found that the essence of understanding such a phenomenon as the soul is a kind of embodiment of the paradoxical combination of apogee and at the same time the extinction of the era of rationality. The symbolism of such a synthesis is explained in the study that Kant, in the process of overcoming the metaphysical heritage, failed to transcend the dogmatic secularization of the western church. The article states that, according to Kant's teaching, anything that is not the realm of "pure reason" in the interpretation of mental manifestations must occupy a secondary and subordinate role. It is established, according to the teachings of Hegel, that it is necessary to subordinate your soul, its intensity to the highest in yourself, that is, to the spirit.

Key words: Hegel, Kant, soul, spirit, mind, transcendence, philosophical anthropology. 